\title{
2: $190752961-190745933$
}

National Cancer Institute

\section{Source}

National Cancer Institute. 2:190752961-190745933. NCI Thesaurus. Code C42370.

Physical location of GDF8_Gene 